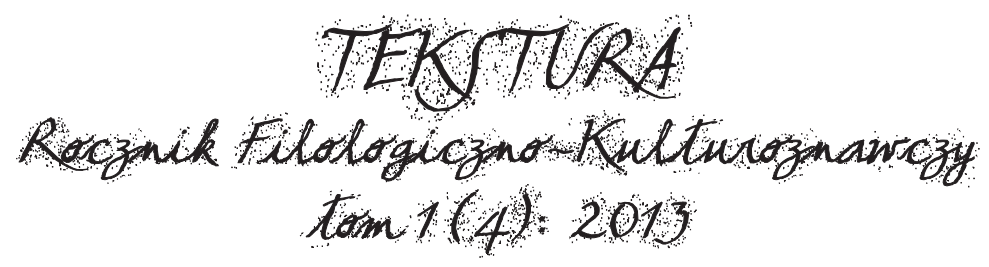

Tomasz Dalasiński

\title{
$\sim$ \\ Syllepsis i sygnatura w POEZji Adama Wiedemanna
}

Sylleptyczność oznacza całkowitą rezygnację z Lejeune’owskiego przekonania o niemożliwości podawania w wątpliwość przez czytelnika sygnaturalnej tożsamości autora, bohatera i podmiotu mówiącego, gdyż podmiotowa sygnalizacja autobiograficzności nie jest już sprawą autorsko-czytelniczego porozumienia, ale obustronnej znajomości reguł i konwencji pisania autobiograficznego. Te reguły i konwencje mają charakter niezwerbalizowanych w tekście retorycznych tropów sprowadzających akt autobiograficzny do poziomu aktu autofikcjonalnego; ujawnienie autofikcji następuje w momencie zdania sobie sprawy zarówno przez autora, jak i przez czytelnika z niemożliwości zaistnienia ich rzeczywistego porozumienia co do autentyczności reprezentowanych $\mathrm{w}$ tekście struktur biograficznych. Porozumienie, które między nimi następuje, jest w zasadzie porozumieniem opartym na planowanym nieporozumieniu przejawiającym się w demaskowaniu iluzyjności referencjalności i autobiograficzności. Autobiograficzność, o jakiej tutaj mowa, dzieje się zawsze „sylleptycznie”, tzn. na przecięciu - jak powiedział Edward Balcerzan - „doświadczeń życiowych pisarza i jego artystycznych fantasmagorii”" realizuje się więc jako nieidentyczność stwarzająca pozory identyczności. Autobiograficzność - czy lepiej: quasi-autobiograficzność - jest więc swoistym „pomiędzy”: prawdą a fikcją, biografią a jej tekstową reprezentacją, „realnością realności” a jej interpretacyjnym konstruktem.

Postępując „sylleptycznie”, Adam Wiedemann zdaje się jednocześnie kreować „domniemanego Wiedemanna” jako podmiot swoich wierszy, jak i pozwalać czytelnikom i komentatorom, z jednej strony, na demaskowanie „do-

1 E. Balcerzan, Powracająca fala autobiografizmu, [w:] tenże, Kręgi wtajemniczenia. Czytelnik-badacz-tłumacz-pisarz, Kraków 1982, s. 385. 
mniemanego" jako nie-realnego poprzez interpretację tekstów, a z drugiej strony - na niezależne od własnych procesów konstrukcyjnych stwarzanie przez nich obrazu sfiguralizowanego „symbolu autora” w języku. Jeżeli w wierszu *** (Już pan nie żyje...) poeta przytacza cudzą wypowiedź (aktualizuje spojrzenie Innego) na temat „domniemanego Wiedemanna”, posługując się przy tym sygnaturą nazwiskową, to nie tyle lokalizuje się w mimetycznie reprezentowanej rzeczywistości, ile sam - mówiąc słowami Witolda Gombrowicza - „staje się literaturą”2:

- Już Pan nie żyje - powiedział. - Już pan nie żyje, panie Wiedemann. - Czekał na moją reakcję. Przyjąłem to w milczeniu. - Gdybym ja tu nie siedział, już by się panu ktoś wpakował w drzwi. I po panu. - Przyznałem mu rację i sobie pomyślałem, no więc dobrze, nie żyję [...].

Ale co tam,

dzisiaj mogę umierać bez przerwy, wielka mi rzecz³.

Pojawiająca się w tym wierszu metafora „umierania bez przerwy” w ściśle określonej teraźniejszości (w „dzisiaj”) niweczy iluzję referencjalności, ponieważ „umieranie” jest elementem szerszego zespołu cech kontekstowych decydującego o tekstowości ,ja”. Podmiot jest tutaj przede wszystkim napisany, choć jego tekstowość ustawicznie - dzięki obecności sygnatury ściera się z możliwością rozpatrywania ,ja” w konfrontacji z biografią poety. Z tego ścierania się „pisania” i „lektury” (z sytuacji lektury-pisania) wyłania się właściwy podmiot wiersza: ,ja” będące wytworem czytelniczej aktywności, która uwzględnia zarówno egzystencjalny, jak i figuralny wymiar sylleptycznego podmiotu. Co więcej, ,ja” staje się tu ,ja” sylleptycznym nie tylko dla czytelnika, ale i dla autora; gest autoreferencji, który zdaje się w tym utworze gestem bazowym, pozwala na łączenie się i przenikanie poziomów podmiotu piszącego (mówiącego) i podmiotu opisywanego (język opisu, który nigdy nie może zaistnieć w stanie czystym, miesza się z metajęzykiem interpretacji przyrodzonej opisowi in statu nascendi). Tym samym „ja” to dla autora „on, którego pisałem” (czy, jak powiedział Kazimierz Brandys, „on, którego tworzyłem”), nietrwały byt, którego „zakończenie” - i to tyl-

2 Zob. W. Gombrowicz, Dziennik (1961-1966), Kraków 1986, s. 245.

3 A. Wiedemann, *** (Już pan nie żyje...), [w:] tenże, Czyste czyny. Wiersze zebrane 1989-2006, posł. A. Skrendo, Poznań 2009, s. 27.

${ }^{4}$ K. Brandys, Dżoker. Wspomnienia z teraźniejszości, Warszawa 1967, s. 238. 
ko chwilowe - jest uzależnione od działań interpretacyjnych. Poprzez swoją sylleptyczność podmiot pokazuje, w jak prosty sposób można zburzyć narzucane sobie schematy, podziały i klasyfikacje; lokalizując się w centrum języka, czyni samego siebie Innym, a więc mimo manifestowanego powinowactwa wypowiedzeniowego ,ja” z ,ja” autorskim wskazuje na niezbywalną rozłączność obydwu instancji. Podmiot Wiedemanna jest zatem i nie jest autobiograficzny (w potocznym rozumieniu tego słowa), wymyka się wszelkim jednoznacznym dookreśleniom, staje się procesem swojej własnej zmienności - i z tego powodu w innym miejscu poeta może pytać: „A życie? gdzie ono?”, dowodząc rów noc zesnej współzależności i rozłączności egzystencji oraz „figurowości” sylleptycznego „ja”.

Sylleptyczność, ogarniająca u Wiedemanna całokształt doświadczenia podmiotowego, doświadczenia tekstu i doświadczenia świata, przenoszona jest dzięki takim działaniom na poziom meta-. Degradacja osoby autora do tekstowej figury, rzeczywistości do skonstruowanej realności oraz wypowiedzi do splotu konwencji i ich przekraczania przy jednoczesnym przeświadczeniu o unikalności i wyjątkowości każdego z tych elementów sprawia, że refleksja ,ja” na temat samego siebie jest refleksją metakulturową, dotyczącą sposobów przejawiania się zmiennego podmiotu w kulturze i odbijania się kultury w podmiocie. To właśnie poprzez sylleptyczność Wiedemann dokonuje rozmontowania modernistycznej podmiotowości idealnej, scalonej, a także nowożytnej kultury „pewnej siebie”, przechodząc od ich „mocnych” koncepcji do wizji ,ja” jako gry znaczeń oraz obrazu kultury jako gry samą sobą. Postępując w ten sposób, poeta zachowuje się zresztą podobnie do Witolda Wirpszy, który - przeczuwając „dekonstrukcjonistyczne” podejście do rzeczywistości - uznał w Czqstkowej próbie o człowieku możliwość uporządkowania świata i samego siebie przez esencjalny podmiot za utopijną mrzonkę, stwierdzając, że kategorię podmiotowości tak naprawdę wyznacza i determinuje język ${ }^{6}$. Jeśli zaś sylleptyczne ,ja” realizuje się w języku i jako język, to w oczywisty sposób komplikuje się najistotniejsza bodaj dla rozumienia takiego podmiotu kategoria, mianowicie: sygnaturalność.

5 A. Wiedemann, Zdobyczne kwalifikacje, [w:] tenże, Czyste czyny, s. 111.

${ }^{6}$ Zob. W. Pietrzak, Śmierć i powrót podmiotu zdekonstruowanego. Cząstkowa próba o człowieku Witolda Wirpszy, „Zagadnienia Rodzajów Literackich” 2011, t. 54, z. 2 (108). 
W klasycznych koncepcjach literatury autobiografizującej (mam tutaj na myśli zwłaszcza koncepcje Philippe’a Lejeune’a ${ }^{7}$ ) sygnatura autorska oznaczała nazwisko w językowej przestrzeni tekstu tożsame nazwisku twórcy oraz użyte $w$ aspekcie autobiograficznym ${ }^{8}$. Ta fundamentalna definicja wynikała z szerszego przeświadczenia literaturoznawców - mającego swoje źródło w filozofii analitycznej - o odpowiedniości między imieniem a jego nosicielem, jeszcze szerzej - odpowiedniości między językiem a bytem. Zgodnie z tym przeświadczeniem, tematyzując swoje istnienie przez jego nazwanie, stwierdzamy to istnienie, łącząc je z prawdą, tzn. odnosimy czyste signifiant do jednostkowego bytu przejawiającego się jako samoidentyczne cogito. Taka sygnatura zawsze dookreśla osobę - w naszym przypadku osobowego autora tekstu, który pojawia się w tekście w pełni swoich tekstowych funkcji; innymi słowy - wymusza ona na czytelniku weryfikację referencji poprzez odniesienie tekstowego wymiaru ,ja” do biografii pisarza. Wydaje się jednak, że w wypadku poezji Wiedemanna lepiej mówić o takiej teorii sygnatury, którą wywieść można z de Manowskich badań nad problemem autobiografizmu9 Teoria ta, przez Andrzeja Skrendę nazwana dekonstrukcyjną ${ }^{10}$, zwraca uwagę na to, że sygnaturalność - funkcjonująca jako parafowanie, czyli złożenie imienia i/lub nazwiska (dodajmy: również ich rozmaitych odpowiedników ${ }^{11}$ ) w tekście lub pod/nad nim oraz datowanie czasowo-przestrzennie sytuujące akt pisania ${ }^{12}$ (a także, jak się wydaje, jako bezpośrednia lub pośrednia wskazówka topograficzna) - jest nie tyle podpisem osobowego (rzeczywistego) autora, ile raczej ujawnieniem pograniczności i niehomogeniczności śladowego „ja”, które w tekście nie pojawia się jako subiectum w pełni swoich funkcji,

${ }^{7}$ P. Lejeune, Wariacje na temat pewnego paktu. O autobiografii, przeł. W. Grajewski i in., red. R. Lubas-Bartoszyńska, Kraków 2001.

${ }^{8}$ Prócz aspektu autobiograficznego sygnatura autorska w obrębie tekstu występować może w aspekcie autotematycznym (obowiązuje zasada „sygnaturalnej” identyfikacji instancji nadawczych) - zob. A. Stoff, O funkcjach sygnatur $w$ literaturze współczesnej, [w:] Ja, autor. Sytuacja podmiotu w polskiej literaturze współczesnej, red. D. Śnieżko, Warszawa 1996.

${ }_{9}$ P. de Man, Autobiografia jako od-twarzanie, przeł. M.B. Fedewicz, [w:] Dekonstrukcja w badaniach literackich, red. R. Nycz, Gdańsk 2000.

${ }_{10}$ Zob. A. Skrendo, Tadeusz Różewicz i granice literatury. Poetyka i etyka transgresji, Kraków 2002, s. 302-303.

11 Takim odpowiednikiem imienia i nazwiska może być np. numer PESEL - zob. np. A. Wiedemann, Czwartek, ulica Gazowa, [w:] tenże, Czyste czyny, s. 132.

${ }^{12}$ Na temat daty jako sygnatury zob. M.P. Markowski, Zagadka daty, [w:] tenże, Efekt Inskrypcji. Jacques Derrida i literatura, Bydgoszcz 1997. 
nie pojawia się jako cogito, ale jako stekstualizowana cielesność będąca pozostałością (śladem) osobowego autora, która stanowi przedmiot podmiotowego doświadczenia ,ja”. Należy bowiem zauważyć, że klasyczna sygnatura - co dostrzegł już Jacques Derrida - nie istnieje, ponieważ z powodu działania języka nie istnieje jej „,własność” w ujęciu filozofii analitycznej (absolutna idiomatyczność) ${ }^{13}$, a jedynie „własność” jako to, co różnicuje się względem innych „własności”, a więc efekt idiomatyczności jako rezultat działań w systemie różnic. Idiomatyczność jako taka jest niemożliwa - konieczność poddania się sygnatury różnicowaniu oznacza jej jednoczesne wywłaszczenie, czyli pozbycie się „własności” - nominacja jest zatem w rzeczywistości przyznaniem się do Inności w sobie i otwarciem na perspektywę czytelniczej kontrasygnaty, która w procesie lektury staje się właściwą, teraźniejszą (a przez to momentową) sygnaturą tekstu. Sygnatura bowiem jest wynikiem negocjacji z sytuacją komunikacyjną przychodzącą z zewnętrza, z kodem, który jest przez nią narzucony, i z kontekstem, w obrębie którego funkcjonuje; tym samym sygnatura stanowi pozostałość spotkania swojego z Innym, która istnieje zawsze jako moment kontrapunktowego różnicowania się tych jakości względem siebie, a nie jako akt samoidentyfikacji.

Sygnatura w tekście literackim nie funkcjonuje więc jako podpis osobowego autora, ale poddaje się ustawicznej literaturyzacji - czy, jak chciał tego Derrida, a za nim Michał Paweł Markowski, staje się efektem sygnatury ${ }^{14}$ - czyli umożliwia wtłoczenie tego, co indywidualne, w to, co systemowe, i sankcjonuje nieustanne powtarzanie i chwilowe konwencjonalizowanie się podmiotu jako znaku. Jeżeli zatem w poezji Wiedemanna pojawia się sygnatura nazwiskowa - jak w cytowanym wierszu *** (Już pan nie żyje...), sygnatura „daty” lub quasi-sygnatura miejsca (zarówno bezpośrednia, jak i pośrednia ${ }^{15}$ ), a więc jeżeli w tekście mamy do czynienia z sygnaturą jako autorską nominacją, to akt tej nominacji jest aktem wyzbycia się własnej obecno-

13 „Jesteśmy wywłaszczeni z upragnionej obecności w użyciu języka, za pomocą którego chcemy nią zawładnąć” - J. Derrida, O gramatologii, przeł. B. Banasiak, Wrocław 1999, s. 217.

14 Zob. M.P. Markowski, dz. cyt.

${ }^{15}$ Interesująca pośrednia quasi-sygnatura miejsca pojawia się u Wiedemanna w wierszu pt. Kochanie (Czyste czyny, s. 191): „»kochanie«, mówi gosposia / do proboszcza, »z ciebie to ale cymbał"”. Na podstawie specyficznej cechy językowej, jaką jest inwersja spójnika i zaimka w dookreśleniu osoby (,z kogoś to ale X”), w wierszu można rozpoznać cechy dialektu południowej Wielkopolski; konfrontując tę informację z danymi biograficznymi, można założyć, że wskazują one na Krotoszyn miejsce urodzenia poety. 
ści i zyskania trwałej nieobecności poświadczanej śladowo. Innymi słowy: „tekst-ciało”, przez który reprezentuje się podmiot, stanowi zarazem sygnaturę autora śladowego i dowód na jego anonimowość (bo, jak zauważył Miron Białoszewski, „,nazwisko to tyle co anonim”"16), choć jest przedmiotem zainteresowania i odniesienia dla podmiotu, ponieważ właśnie poprzez tekst - jako „ciało” - ,ja” jest w stanie uchwycić i zaprezentować swoją zmienną tożsamość, nawet jeśli będzie to tożsamość nieautentyczna, bo nieodnosząca się do sfery transcendencji, nieprzekraczająca sfery zmysłowości i namacalności:

To może jeszcze po oddechu. Dla każdego?

Tak myśli ktoś, kto przed chwilą umył się lub wysrał.

Obydwie te czynności nie dotyczą ducha, dotyczą nazwy własnej, która się oczyszcza, brudząc wodę i spłuczkę. Czystka rodzi ${ }^{17}$.

Nazwa własna - z definicji semantycznie pusta - nie jest zatem tym, co może służyć określaniu się podmiotu jako podmiotu sytuującego się wobec własnego jestestwa. Stekstualizowana cielesność (jako nazwa, sygnatura „ja”) jest jednocześnie obiektem i podmiotem doświadczania tekstu, choć należy pamiętać, że cielesność - to, co zawsze zmienne w tym, co pozornie stałe - poprzez swoją ruchomość i dynamizm dyseminuje ciało, w związku z czym ciało (tekst) nie może być postrzegane jako modernistyczny bastion sensu, ale jako „drugonowoczesny” proces jego zyskiwania i tracenia.

Cielesność - jako wydarzanie się tekstu i przydarzanie-się sobie podmiotu - wydaje się metaforą niezwykle trafną w wypadku analizy procesów sygnowania w wierszach Wiedemanna. Cielesność jest bowiem tym, co jest dane podmiotowi-chłopcu, tj. takiemu podmiotowi, który nigdy nie jest gotowy na „męskość”, na ostateczne zamknięcie siebie jako monolitycznej obecności, choć jest bezustannie obietnicą takiej obecności mamiony:

chłopiec przed chłopcem bardzo tym zdziwiony na ile życia już sobie pozwolił

${ }^{16}$ M. Białoszewski, O tym Mickiewiczu jak go mówię, [w:] Debiuty poetyckie 1944-1960. Wiersze, autointepretacje, opinie krytyczne, wyb. i oprac. J. Kajtoch i J. Skórnicki, Warszawa 1972, s. 294.

17 A. Wiedemann, Pensum, [w:] tenże, Czyste czyny, s. 226. 
i patrzy przez to życie temu chłopcu

w oczy i widzi chłopca którym był nim przepadł

w tych albo innych oczach którymi się bawił

jak zapałkami i patrzył jak płoną

i się odwracał od nich ledwo zgasły ${ }^{18}$.

Podmiot-chłopiec postrzega swoje ciało jako nigdy nieuformowane przez swoją cielesność, jako amorficzny proces tworzenia uzależniony od spojrzenia Innego ${ }^{19}$. Dla podmiotu to, co tekstowe, jest masą pozbawioną kształtu, estetyczną ekspozycją zawsze jakiejś, ale i zawsze innej, cielesności (aktualizacji ,ja”), która nie ma na celu tworzenia narracji na temat podmiotu, tzn. opowiadania o ,ja” zmediatyzowanym w ciele, nie ma zatem na celu skonstruowania ciała, ale raczej ostateczne zamilknięcie ,ja” jako skończonej osoby, która - jak u Jeana-Luca Nancy’ego - bezpośrednio zlewa się z pisanym tekstem i notorycznie wyswobadza się z piętna logocentrycznego sensu ${ }^{20}$. Cielesność - poprzez „rozpisywalność”, możliwość poddawania się utekstowieniu - stanowi swoją własną niewyrażalność jako struktura obecności, a jednocześnie - wyrażalność swojego nosiciela (autora) jako nieobecności poświadczanej w tekście śladowo. Cielesność sytuuje się na pograniczach dyskursów unieobecniających realną obecność, a więc pisanie-ciała (nie pisanie o ciele, bo ciało nie poddaje się - z powodu swojego nie-zaistnienia - tematyzacji) jest nieustanną dialektyką zbliżeń i oddaleń tekstu od cielesności, nieustanną grą ontologizacji i dezontologizacji podmiotu. Ta gra nie oznacza jednak, rzecz jasna, zakwestionowania prób opisów „,ja” w tekście, ale wyklucza proste pozatekstowe odniesienie tych opisów. Podmiotowość nie ma bowiem żadnej apriorycznej (osobowej) tożsamości, która mogłaby być mediatyzowana w tekście; operuje ona jednak zmiennym dystansem między własną tekstualnością a śladami osobowej empiryczności. Dystansem, który w żaden sposób nie może zostać zniwelowany ani przekroczony, dystansem, który jest podmiotowym stanem wykluczającym zarówno jego zdestruowanie, jak i pełną transgresję - choć niewątpliwie pozwalającym na pojawie-

18 Tenże, *** (chłopiec przed chłopcem), [w:] tenże, Czyste czyny, s. 147.

19 Zob. w tym kontekście taką uwagę Jacques’a Lacana: „Pierwszym obiektem pragnienia jest być przez innego uznanym" - tenże, Funkcja i pole mówienia i mowy w psychoanalizie, przeł. B. Gorczyca i W. Grajewski, Warszawa 1996, s. 8.

20 J.-L. Nancy, Corpus, przeł. M. Kwietniewska, Gdańsk 2002, s. 47. 
nie się przeczucia istnienia czegoś poza ,ja”, mimo że to coś, jak w wierszu 2. O oddychaniu z cyklu Pięć małych traktatów, jest ezoteryczne, niedefiniowalne i pochodzące „nie wiadomo skąd”, i mimo że podmiot jest od tego czegoś nieustannie odgrodzony (metafora ręcznika):

Raz w życiu byłem w saunie i wszyscy tam byli

poubierani w ręczniki i oddychali parą,

oddychali parą wodną, która nachodziła

nie wiadomo skąd, aby ich oczyścićéc ${ }^{21}$.

Cielesny wymiar doświadczenia podmiotu w materii tekstu jest również tym, przez co ,ja” zyskuje namiastkę własności z powodu niemożliwości całkowitej translacji jego zmiennej tożsamości w mniej lub bardziej zobiektywizowny i uniwersalny dyskurs oraz jej pełnej artykulacji w tym dyskursie. Wydaje się, że poezja Wiedemanna sytuuje się dzięki temu w obszarze „poetyki doświadczenia”, będącej próbą - jak zauważył Nycz - „reinterpretacji kategorii bezpośredniości, sposobu powiązania tego, co zmysłowo-cielesne z tym, co myślowo-dyskursywne, a także [...] [poszukiwania - przyp. T.D.] niedualistycznego sposobu odnoszenia się języka do rzeczywistości”22. Próba wyjścia z filozofii dualizującej, znana chociażby z rozważań Josefa Mitterera $^{23}$, u Wiedemanna realizowana jest poprzez inwazję sensualności (i seksualności), które, choć nie określają „mocnej” obecności podmiotu, to jednak bardzo wyraźnie wskazują na jego (nie)obecność, tj. na pozostawione przez „ja” ślady swojego nieistnienia-w-pełni. Ślady te pozostawione są, rzecz jasna, w samym języku; jeżeli bowiem uznać Wiedemannowską „poetykę doświadczenia” za próbę wyjścia z dualizowania, to należy jednocześnie zauważyć, że język staje się u niego samą cielesnością, że przejmuje on funkcje podmiotowe, że to właśnie on w ten czy inny sposób determinuje podmiotowe doświadczanie ciała-tekstu ${ }^{24}$. „Cielesnojęzykowość” - jeśli można po-

\footnotetext{
21 A. Wiedemann, 2. O oddychaniu, [w:] tenże, Czyste czyny, s. 158.

${ }^{22}$ R. Nycz, Antropologia literatury-kulturowa teoria literatury-poetyka doświadczenia, ,Teksty Drugie” 2007, nr 6, s. 40.

${ }^{23}$ Zob. np. J. Mitterer, Tamta strona filozofii, przeł. M. Łukasiewicz, Warszawa 1996.

${ }^{24}$ Zastanawiająca jest w tym kontekście zbieżność koncepcji poetyckiej Wiedemanna z taką deklaracją Andrzeja Sosnowskiego: „Język to jest głównie muzyka atmosferyczna i ciało, cielesność w innym stanie skupienia, w innym stadium materii. Skoro można pomyśleć materialność światła, to czemu język nie miałby być subtelną, acz materialną formą obecności ciała w przestrzeni?" - Jedynie słowa są tym,
} 
służyć się takim neologizmem - jest tym, co ustawia podmiot w poezji Wiedemanna jako nigdy niezrealizowany obraz ,ja” dla „ja”, jako niemożliwość swojego własnego spełnienia, jako bezustanne doświadczanie samego siebie w swojej amorficzności i niepełności. Towłaśnie język ochrania tę „resztę”, ten ślad empiryczności, w którym podmiot doświadcza i wypowiada tymczasowego siebie na swojej ostatecznej ontologicznej granicy.

Koncepcje „tekstu-ciała” i podmiotu/cielesności/językowości jako dalsze implikacje dekonstrukcyjnej teorii sygnatury wskazują na kilka istotnych kwestii: po pierwsze - na istnienie w tekstach takich deskrypcji ,ja”, których w żaden sposób nie da się sprowadzić do tekstualno-empirycznych reprezentacji śladów autorskich. Po drugie - na to, że konstruowanie podmiotowości ma charakter procesualny i, tym samym, wykracza poza ramy jednego utworu. Po trzecie wreszcie - że poszukiwanie przez podmiot tożsamości jest problemem antropologicznym. Jeśli bowiem sygnatura stanowi stekstualizowany ślad empiryczności autora (nawet jako jego nieobecności), to wszystkie tego rodzaju ślady można scalić w hipotetyczną tożsamość podmiotową, nawet jeśli byłaby to tożsamość niespójna i z założenia likwidująca autora osobowego, a więc - likwidująca samą tożsamość. Taka zdekonstruowana tożsamość uwzględnia - bo uwzględniać musi - szerokie spektrum kulturowe, tj. kwestie społeczne, historyczne, estetyczne, etyczne itp., które determinują kształt zdezintegrowanej i zdezautonomizowanej (w stosunku do języka) podmiotowości. Kształt, który nigdy nie ma charakteru ostatecznego, jest permanentnym procesem zyskiwania i tracenia tożsamości w konstrukcjach autobiograficznych o rozmaitych strukturach (od struktur zhierarchizowanych i zlinearyzowanych do konstrukcji wewnętrznie sprzecznych i odrzucających gradacyjność oraz chronologię na rzecz chaotyczności). Powtórzmy: brak metafizycznego modelu ,ja” nie wyklucza w poezji Wiedemanna poszukiwania podmiotowej tożsamości. Nawet jeśli tożsamość ta jest nieciągła, nielinearna, niespójna i zdezintegrowana, nawet jeśli narracja ma charakter pozornie nietożsamościowy, podmiot zawsze w jakiś sposób odwołuje się do pozatekstowych wzorców identyfikacji, uwzględnia perspektywę referencji, choć perspektywa ta jest poddawana ustawicznej krytyce i dekonstruowana, a więc nierealizowana jako proste odniesienie biograficzne. Tożsamość zde-

co się mówi. Z Andrzejem Sosnowskim rozmawia Karol Pęcherz, „Magazyn Materiałów Literackich Cegła”, nr 7, http://magazyn-cegla.net/index.php?p=5\&id=8, dostęp: 12.04.2012. 
konstruowana nadal zatem pozostaje tożsamością, która realizuje się jako quasi-narracja tożsamościowa w autokonstrukcyjnych czynnościach podmiotu jako własnego przedmiotu istniejącego w czasie i w nim pozostającego. Podmiotu, który jest świadomy własnej dyskursywności, własnej zależności od kultury, a tym samym - braku niepowtarzalności i jednostkowości, konieczności pozostawania w takich czy innych schematach (pozorna oryginalność okazuje się bowiem niczym więcej niż intertekstualnym kodem, summą przytoczeń, które trzeba na serio bądź ironicznie interpretować). Warto zauważyć, że ta konieczność wynika także z faktu wielokrotności, reprodukowalności sygnatury, która rozbija tożsamość (samoidentyczność) podmiotu jako zdarzenia „tu i teraz”. Dzieje się tak z powodu tego, że tekst sygnowany nie jest własnością sygnującego, ale własnością Innego przypisującego własność sygnującemu. Takich przypisań nastąpić może nieskończona liczba, a każde z nich odsyła do innego wyobrażenia sygnującego, gdyż - jak to zostało powiedziane - absolutna idiomatyczność pozwalająca na temporalną samoidentyczność sygnującego jest niemożliwa. Tym samym sygnatura - powtarzana i powielana - staje się sygnaturą sygnatury, odsyła tylko do wyobrażonego, do pisma, do znaku, do śladu, de facto - do jakiejś nieobecności. Okazuje się zatem, że sygnatura nie jest jedynie podpisem, ale jest wyobrażeniem jakiejś całości, jest (za każdym razem innym) wyobrażeniem tekstu - i podmiotu - jako całości nigdy nieobecnych, choć przywoływanych w śladach.

Jeżeli sygnaturalność w poezji Wiedemanna odsyła zawsze do (nie)obecności, to autobiograficzność musi być tutaj rozumiana, po pierwsze, jako efekt autobiograficzności (podobnie jak „powieściowość” - le romanesque Rolanda Barthesa w Roland Barthes par Roland Barthes jest efektem powieści), a więc jako naśladowanie zbioru konwencji w celu ich zanegowania i przekroczenia na dalszym planie, a po drugie - jako modalność, figuralność: nie jako rzeczywista opozycja tekstualności i empiryczności, ale jako ich wzajemny związek, stan zawieszenia, sytuacja, w której alternatywność i ustawiczne zastępowanie się fikcjonalności i niefikcjonalności stanowią zasadnicze sposoby przejawiania się podmiotowości. Autobiograficzność nie jest zdarzeniem się tekstu-podmiotu, ale jego ustawicznym zdarzaniem się, stanem tropologicznego istnienia podmiotowości, którego nie sposób zamknąć w żadnej stałej i niezmiennej formie. Sygnaturalność w takim kontekście nie podlega weryfikacyjności, nie podpada pod rozstrzyganie autentyczności bądź nieautentyczności ,ja”; jest figurą, tropem podmiotowości. Nie wyznacza zatem ona autobiograficznego (w Lejeune’owskim 
rozumieniu) wymiaru tekstu, czyli takiego wymiaru, w którym w tekście literackim do głosu dochodzi osobowy autor. Wyznacza pewną specyficzną, podmiotową, figuralną i tropologiczną konstrukcję tożsamościową, która, choć mediatyzuje ślady empirycznej obecności, nie stawia sobie za zadanie referencyjnego dookreślania faktyczności nawiązań biograficznych, ale konstruowanie podmiotowości jako tekstowego stanu sylleptycznego, dla którego nie istnieje żaden realny i skonkretyzowany referent (gdyż następuje albo rozproszenie, albo nieobecność referentów). Można więc powiedzieć, że w poezji Wiedemanna mamy do czynienia z autobiograficznością niemetafizyczną, z autobiograficznością bez autora osobowego, choć z tekstualnie zaświadczanymi śladami jego uprzedniego względem tekstu-podmiotu istnienia. To autobiograficzność przeniesiona na poziom meta, autobiograficzność odsłaniająca metody konceptualizowania samej siebie jako retoryki czytania tekstu-podmiotu. Wiedemann bowiem zdaje się - na różne sposoby - dowodzić, że opisanie (w rzeczywistości napisanie) siebie nie jest do końca możliwe; czyni tak zwłaszcza tam, gdzie, koncentrując się na trybach narracji autobiograficznych, nieustannie (i ironicznie) je dekonstruuje przez stosowanie technik nakładania się tekstów (tekst w tekście) lub podważania wcześniejszych sądów późniejszymi względem nich komentarzami, dopowiedzeniami, odnoszącymi się do nich pytaniami itp.:

Oni nie sq chorzy, tylko martwi, mówi Jarek o swoich bohaterach, nie można ich uzdrowić. Potem wypalamy jeszcze po papierosie i idziemy do miasta ${ }^{25}$.

O stare nieba! (tak mi się powiedziało). Tysiąc daje się sprawdzić, ale nie przeżyć. Dla przyjemności sprawdzenia poświęcamy tyle miłych pieśni.

Ta pieśń ma charakter religijny (powiedzmy) ${ }^{26}$.

Ten wiersz się łączy z poprzednim. Słońce nie ma twarzy, zwłaszcza dzisiaj. Poprzednio brało sobie urlop i mogliśmy wyjść z pracy, patrzeć prosto w ciemność. [...]

To takie proste: otwierasz usta i coś z nich wychodzi, i nie jest to bynajmniej język

${ }^{25}$ A. Wiedemann, Gwałtowne pogorszenie samopoczucia, [w:] tenże, Czyste czyny, s. 62 .

${ }^{26}$ Tenże, [tysiq̨c], [w:] tenże, Czyste czyny, s. 220. 
w stanie czystym. [...]

Forma tego wiersza nie pozwala na powiedzenie czegoś więcej²7.

Wykorzystywane przez Wiedemanna techniki metajęzykowe i metafikcjonalne wewnętrznie tematyzujące literackość wypowiedzi, tj. czyniące problem języka przedmiotem swoich przedstawień, służą konstruowaniu iluzji powstawania tekstu - a tym samym jego podmiotu - na oczach czytelnika. Sprawia to, że ontologiczne podstawy tekstu autobiograficznego - takie, o jakich mówią esencjaliści - są znoszone, ponieważ to, co w pierwszym odbiorze postrzegane jest jako fakt, w rzeczywistości okazuje się z nakiem; tym samym podmiot jest sam dla siebie i dla Innego znaczącym, które nie odwołuje się do niczego poza swoim własnym znaczeniem, a zatem istnieje jedynie językowo poprzez tworzenie person (masek) służących pozornej autoidentyfikacji. Persony te nie kryją jednak niczego poza bezustanną semiozą, grą znaczących; autobiograficzność ,ja” staje się w takiej sytuacji autobiograficznością złożoną z fragmentów, które postrzegać trzeba w perspektywie odwrócenia przekonania o całościowym (całościowo dostępnym) charakterze tożsamości jako konstrukcji psychicznej. Odwrócenie to polega na podważaniu bądź negowaniu przyczynowości jako siły sprawczej autobiografii - w miejsce wzajemnych oddziaływań przyczyn i skutków pojawia się fragment jako ustawicznie aktualizowana forma przeciwstawiona stałemu kompleksowi (zgodnie z sądem Umberto Eco, że „pierwszym rodzajem twierdzeń o świecie i człowieku, do jakich sztuka ma prawo i jakie mają naprawdę znaczenie, są twierdzenia wypowiadane za pomocą odpowiednich form, a nie kompleksu sądów wartościujących o danym przedmiocie”28). Tym samym tekst staje się nie tyle środkiem komunikowania (o czymś), ile elementem podmiotowego doświadczenia samego siebie i rzeczywistości, przede wszystkim - rzeczywistości wytwarzania tekstu. Oznacza to, że autobiograficzność jest pewnym projektem epistemologicznym myśli „słabej”, w ramach którego pluralność wyzwala się z więzów całości ujednolicających doświadczenie (wielość zatem zastępuje całość i nie jest do niej sprowadzalna).

\footnotetext{
7 Tenże, Estetyka słowa, [w:] tenże, Czyste czyny, s. 172.

${ }^{28}$ U. Eco, Poetyka dzieła otwartego, [w:] tenże, Dzieło otwarte. Forma i nieokreśloność w poetykach współczesnych, przeł. J. Gałuszka i in., Warszawa 1994, s. 279-280.
} 
Sfragmentaryzowana autobiograficzność w poezji Wiedemanna wprowadzana jest w obręb tekstów w perspektywie aktualności pisania, a nie zapamiętanej i rekonstruowanej przeszłości. Materiał biograficzny poddawany jest procesom dyskursywizacji, co sprawia, że autorskie refleksje na temat własnej biografii nie są w tekście prostym zapisem myśli (uniwersalną ramą reprezentacji), ale swego rodzaju matrycą umożliwiającą generowanie fragmentarycznych konstrukcji w sylwicznych (w rozumieniu Nycza) odcinkach. Odcinki te nie są od siebie uzależnione w sposób przyczynowo-skutkowy, ale mimo tego są wzajemnie powiązane jako relacje między kolejnymi teraźniejszościami biograficznymi podmiotu, innymi słowy: między kolejnymi aktualizacjami ,ja”. Następstwo tych nieciągłych teraźniejszości to najważniejszy wyznacznik autobiograficzności w takim kształcie, w jakim jest ona proponowana w wierszach autora Samczyka - wydaje się, że czasowościowa struktura ,ja” opiera się tutaj właśnie na następstwach teraźniejszych momentów; problem ten wymaga, oczywiście, analizy w ramach odrębnego studium. 